Mediterranean Journal of Humanities mjh.akdeniz.edu.tr I/ 1, 2011, 71-81

\title{
Intercultural Communication in the Age of Globalization and English Language Teaching
}

\section{Küreselleşme Çă̆ında Kültü̈rlerarası İletişim ve İngilizce Ëğitimi}

\author{
Yeşim Bektaş ÇETINKAYA* \\ "Wider access to more people will be a doubtful victory if human beings find they have nothing to say to \\ one another or cannot stand to listen to each other" (Barnlund, 1991, 23).
}

\begin{abstract}
The current age of technology and globalization allowed people from various cultures to encounter one another more than ever. In this context, English has emerged as a worlid language which is used from international trade to international media, and contributed to the increase of communication among nations. Thus, intercultural communication concept which investigates the process of communication among people of various cultures has gained importance. This paper first illustrates the communication studies' (psychological) approach to intercultural communication by discussing how they define culture, and communication, and how they approach intercultural communication. Second, it explains the discourse approach to intercultural communication and discusses how the discourse approach differs from the communication studies' approach. Third, it demonstrates the critical approaches to using English for intercultural communications. Finally, it discusses how intercultural communication can be addressed in language classrooms.
\end{abstract}

Keywords: Intercultural communication, culture, English language teaching, intercultural competence

Özet: Günümüzün hızla küreselleşen teknoloji çağında farklı kültürlerden bireyler daha önce benzeri görülmemiş bir şekilde bir araya geliyor, etkileşiyor. Bu ortamda, İngilizce uluslararası ticaretten medyaya kadar her alanda bir dünya dili olarak ortaya çıkıyor ve ülkeler arasında iletişimin artmasına katkıda bulunuyor. Böylece, farklı kültürden bireyler arasındaki iletişim sürecini ifade eden kültürlerarası iletişim kavramı giderek önem kazanıyor. Bu çalışma öncelikle kültür ve iletişim kavramlarını nasıl tanımladıkları ve kültürlerarası iletişime nasıl yaklaştıklarını tartışmak suretiyle, kültürlerarası iletişim kavramına iletişim çalışmaları (psikolojik bakış) bakış açısını ortaya koyuyor. Sonrasında kültürlerarası iletişim kavramına söylem yaklaşımını ve bu yaklaşımın iletişim çalışmaları yaklaşımından nasıl farklılaştığını açıklıyor. Daha sonra İngilizce nin kültürlerarası iletişimde kullanılmasına yönelik kritik yaklaşımları ortaya koyuyor. Son olarak, kültürlerarası iletişimin dil sınıflarında nasıl ele alınabileceğini tartışıyor.

Anahtar Sözcükler: Kültürlerarası iletişim, kültür, İngiliz dili eğitimi, kültürlerarası yeterlilik

The current age of technology and globalization allowed people from various cultures to encounter one another more than ever. Transportation technology allowed us to travel anywhere within hours, and communication technology made it possible to have instant oral, and graphic communication without traveling. (Porter, Samovar, 1991). Moreover, the emergence of multicultural business associations, or international organizations increased the contact among people and required effective intercultural communication skills. In this context, English has emerged

\footnotetext{
* Öğr. Gör. Dr., Dokuz Eylül Üniversitesi, Buca Eğitim Fakültesi, Yabancı Diller Eğitimi Bölümü, Buca, İzmir, yesim.cetinkaya@deu.edu.tr
} 
as a world language which is used from international trade to international media, and contributed the increase of communication among nations. Thus, the intercultural communication concept which investigates the process of communication among people of various cultures has gained importance.

In the U.S.A. the field of intercultural communication emerged in 1950s with the work of linguist Lado, who linked the language and culture within educational framework and US Foreign Service Institute officer Hall, who developed the principles of intercultural communication to guide the Peace Corp staff (Kramsch, 2001). Early studies of intercultural communication focused on miscommunication, and comparative studies of mostly American and Asian cultures. In 1970s the knowledge gained from these studies were mainly used by international business society. Later, in 1980s international communication studies began to pay attention to interethnic conflicts within the U.S.A and informed teachers and social workers (Kramsch, 2001). Since then, with the Scollon and Scollon's study of Athabaskans, intercultural communication has been studied not only from psychological perspective but also from sociolinguistic and linguistic anthropology perspectives. Recently, scholars like Pennycook $(1994,2001)$ approached the intercultural communication in English from critical perspective in relation to power and control.

In English Language Teaching (ELT) field, the redefinition of English as an international language, which is used by various nations to communicate with each other has lead to reconceptualization of communication, and the role of culture in English language pedagogy. It is argued that the intercultural communications in English take place not only between native and nonnative speakers of English but also among nonnative speakers of the language. Thus, instead of teaching English by taking native speaker of English and her culture as a norm, it is proposed to teach English as an international language by taking bilingual speakers who can function in multiple cultures as a norm. Therefore, the notion of "intercultural communicative competence" has emerged as the new goal of English language learning by replacing native speaker based notion of "communicative competence" (Alptekin, 2002; Byram, 1997).

In this paper, I first illustrate the communication studies' (psychological) approach to intercultural communication by discussing how they define culture, and communication, and how they approach intercultural communication. Second, I explain the discourse approach to intercultural communication and discuss how discourse approach differs from communication studies' approach. Third, I demonstrate the critical approaches to using English for intercultural communications. Finally, I discuss how intercultural communication can be addressed in language classrooms.

\section{Communication Studies: Psychological Approach to Intercultural Communication}

Within the communication studies, there are different ways of conceptualizing and exploring intercultural communication including intercultural, international, and development communication. While international communication and development communication deal mostly with mass communication, intercultural communication studies mostly focus on communication at interpersonal level (Gudykunst, \& Mody, 2002). In this section, I mostly focus on intercultural communication, since throughout the paper, I examine intercultural communication as the communication process among individuals from various cultures. I consider that intercultural communication happens at interpersonal level although individuals are situated in culture(s) (discourses).

International Communication studies examine "mass-mediated communication between two or more countries with differing backgrounds" (Rogers, \& Hart, 2002, 5). The unit of analysis for this kind of communication is interaction between two or more nations which takes place at societal level through technological instruments such as radio, television, and computer networks. The scholars in this field have studied the flow of information and news throughout 
the world, the world view that these news carry and the asymmetry of the information flow which favors Western nations. Recently, International Communication Studies focus on "the role of communication satellites, telecommunication, and the diffusion of the Internet, its consequences, and on the digital divide between developed and developing nations" (Rogers, \& Hart, 2002, 9).

Development Communication is defined as "the study of social change brought about by the application of communication research, theory, and technologies to bring about development" (Rogers, \& Hart, 2002, 9). The main purpose of Development Communication studies is to investigate how mass media such as radio and television can be used in developing countries to lead social change in areas such as healthcare, literacy, and agriculture. Recently, Development Communication field focuses on issues such as globalization, informatization, entertainmenteducation, and privatization. On the other hand, intercultural communication "examines the interpersonal dimensions of intercultural communications as it occurs in a variety of contexts" (Samovar, \& Porter, 1991, 2).

According to Porter and Samovar (1991) intercultural communication happens when a message which is encoded in one culture need to be decoded in another culture. Thus, the notions of communication and culture are the two main components of intercultural communication. In order for communication to happen, there needs to be a 'behavioral source' -a person who is willing to communicate-, and this source needs to 'encode' a message through internal activity of choosing verbal and nonverbal behaviors. Then, this encoded 'message' needs to be sent from source to responder through a 'channel'. When the 'responder' gets the message, she 'decodes' the message and sends a 'response'. Finally, the 'source' evaluates the effectiveness of the communication depending on the information available to her. This final process is called the 'feedback' (Porter, \& Samovar, 1991).

Porter and Samovar (1991) consider communication as a dynamic, interactive process in which two or more people bring their backgrounds, and experiences to communication process and constantly affect each other. Furthermore, communication occurs in a physical and social context, which defines the nature of the communication. The physical aspect of the environment (e.g. comfort of a chair, or the color of the walls) may affect the communication as well as the social context (e.g. social relationships between people, the form of language used, or personal moods) (Porter, \& Samovar, 1991).

The second component of intercultural communication, culture, is defined as the "cumulative deposits of knowledge, beliefs, views, values, and behaviors acquired by a large group of people and passed on from one generation to the next" (Samovar, \& Porter, 64). Culture shapes the individual identities and affects one's perception, verbal, and non-verbal processes. For instance, one's social perception of object and events are constructed depending on the culture one lives in. Thus, one's beliefs, values, attitudes, and world view are shaped within her culture. The values that people held in relation to goodness, usefulness, or pleasantness of events and objects change from one culture to another as the belief system of those people (Argyle, 1991; Hall, 1991; Porter, \& Samovar, 1991). Similarly, the verbal processes (language, thought patterns, etc.) and nonverbal processes (concept of time, use and organization of space, eye contact, touching, etc.) differ from one culture to another.

Another cultural notion is defined as world view which refers to "how people view themselves, each other, and their places in the universe" (Samovar, Porter, 1991, 65). One's world view (her orientation toward God, humanity, nature, the universe, and others that are concerned with the concept of being) is believed to determine how one interacts with other people within or across cultures. In intercultural communications, not only different world views but also various other factors are identified as affecting communication breakdowns: assuming similarity instead of difference, language problems, nonverbal misunderstandings, the presence of preoccupations 
and stereotypes, the tendency to evaluate, and high anxiety (Barna, 1991). Barna (1991) states that similarities among people are mainly biological, and even though the spread of western culture creates some kind of false similarity among cultures, people from different cultures need to start communication assuming differences between cultures. The best approach to intercultural communication is "to develop an investigative, nonjudgmental posture, and a high tolerance for ambiguity-all of which required lowered defense" (Barna, 1991, 348).

Although Barna (1991) identified language differences as another difficulty in intercultural communications, she does not elaborate subject other than arguing that even though one learns a foreign language, meaning of a word or a pharese that she uses may have different connotations in that langauge. The third factor that leads to communication breakdown is the nonverbal misinterpretations. People from different cultures have different nonverbal ways of conveying meaning. They may not understand or even notice the nonverbal signs that the other cultures use. Barna (1991) states "they see, hear, feel, and smell only that which fits into their personal world of recognition and then interpret it through the frame of reference of their own culture" (349). Stereotypes, which are "the over-generalized second-hand beliefs that provide conceptual bases from which we make sense out of what goes on around us" (Barna, 1991, 349) can cause communication breakdown. The tendency to evaluate people depending on one's cultural values may also cause communication breakdowns. Finally, the anxiety that one feels "due to the number of uncertainties present and the personal involvement and risk" may lead to communication breakdown.

In communication studies, cultures are classified as high- and low-context cultures (Hall, 1991); and individualistic and collectivistic cultures (Triandis, Brislin, \& Hui, 1991; Yum, 1991). In high- context cultures, in communication "most of the information is either in the physical context or internalized in the person" (Hall, 1991, 48) while in low-context cultures, "most of the information is vested in the explicit code" (Hall, 1991, 48). American culture is considered a low-context culture, in which most of the information in communication processes carried by verbal expressions; whereas Chinese culture is considered high-context culture, in which one needs to have contextual knowledge in order to decode the message. In high-context cultures, it is believed that since so much information is available in the environment, it is not necessary to state the obvious.

Another classification that differentiates cultures is individualism-collectivism. While "collectivism is characterized by individuals subordinating their personal goals to the goals of some collectives, individualism is characterized by individuals subordinating the goals of collectives to their personal goals" (Triandis, Brislin, \& Hui, 1991, 371). Individualism is believed to be the cultural characteristics of North America and Western Europe, where individuals are autonomous, separate from groups, and determine their behaviors. Individualistic societies are claimed to value freedom, honesty, social recognition, comfort and hedonism. On the other hand, collectivism is believed to be the cultural characteristic of Asia, Africa, South America, and the Pacific, where individual is defined as a part of a group. Collectivistic cultures are argued to value harmony, face saving, modesty, moderation, and fulfillment of others' needs.

Psychological approaches to intercultural communication can be considered a starting point, where American scholars attempted to make sense of intercultural communication and identified some aspects of it within western cultures' framework. It is a starting point because most of the issues are explained in a simplistic nature. Communication is defined in terms of a process of encoding and decoding a message in the mind of a person. Furthermore, the language aspect of intercultural communication is overlooked, learning a foreign language, and communicating in a 'foreign language' are not addressed. Culture is defined as static entity and homogeneous within the nation or ethnic group. Furthermore, cultures are classified in relation to western or American 
culture by creating a dichotomy of us (western culture) versus others (all the other cultures in the world). On the other hand, this approach identified the importance of culture, and context in intercultural relations which may lead us to further examine the nature and role of culture.

\section{Discourse Approaches to Intercultural Communication}

Scollon and Scollon (2001), representatives of the discourse approach, differentiate their way of studying intercultural communication (interdiscourse approach) from the way the communication studies approach it (cross-cultural). According to Scollon and Scollon (2001) while crosscultural communication studies compare the "communication systems of different groups when considered abstractly or when considered independently of any form of social interaction", interdiscourse communication studies examine communications "when members of different groups are directly engaged with each other" (13). Although, they find cross-cultural studies useful to form preliminary hypotheses, they maintain that ultimately it becomes restricting. Therefore, Scollon and Scollon (2001) promoted interdiscourse communication and emphasized the social interaction between people rather than comparing abstract differences between members of different cultures.

Scollon and Scollon (2001) call their approach interdiscourse communication rather than intercultural communication because they argue that the "concept of culture is too broad to be of practical use" (Scollon, 2001, 311) and "cultures are a different level of logical analysis from the individual members of cultures. Cultures do not talk to each other; individuals do" (Scollon, \& Scollon, 1995, 125). It is argued that individuals do not represent cultures, even though they are situated within the culture. Furthermore, Scollon and Scollon (2001) argue that some aspects of cultural differences do not play a major role in interdiscourse communications. For instance, they state that religious belief which may be central to a business man may not be a significant factor in a particular business meeting. Moreover, they assert that while verbal communication is the central aspect of interdiscourse communication, nonverbal communication does not play a significant role as claimed earlier.

By following Gee, Scollon and Scollon (2001) defined discourse as "ways of being in the world, or forms of life which integrates words, acts, values, beliefs, attitudes, and social identities, as well as gestures, glances, body positions, and clothes" (Gee cited in Scollon, \& Scollon, 2001, 538). According to Scollon and Scollon (2001) each person is a member of various discourse systems such as gender, generation, occupation, region, ethnicity, etc., and during communication, each individual is positioned within number of these discourses. For instance, in a day-to-day communication, one may be a woman, a professional, and a mother simultaneously and each of these discourses may be in conflict with each other.

The focus of interdiscourse communication is the social interaction of different people and their interpretations of this communication process that takes place culturally diverse situations. Scollon and Scollon (2001) assume that communication, as a social action, is non-conscious act, which comes naturally to a person from her "accumulated experience of society both within and across group boundaries" (269). Furthermore, whenever a person communicates, she positions her in a particular social group, and hence produces 'others', who do not belong to that particular group that she has identified with. It is argued that in order to define 'self' one needs to identify the 'other', and each communication creates 'self' and 'other'.

The unit of analysis in interdiscourse communication is neither system of cultures as in cross cultural communication nor individuals as representative of those cultures but "the person in the moment of taking social action" (Scollon, Scollon, 2001,268), "people-in-action', who positioned in multiple discourse systems. By following the methodologies of interactional sociolinguistics, the main methodology that Scollon and Scollon apply to research interdiscourse communication is ethnography, which Scollon (2001) suggests to mean "a rather broad 
perspective on issues and an insistence on contextualizing observations" (310).

According to Scollon and Scollon ethnographic research methodology consists of four components: fieldwork, participant observation, strange making, and contrastive observation. Field works refers to investigating naturally occurring phenomenon rather than manipulated one. Consequently, the role of the researcher in this context is observation as a participant of the situation. Then, the researcher presents this familiar phenomenon as if it is not familiar. Finally, she compares the actions of observed people with the people of other places, and times. Ethnographers produce their data in the forms of photography, video, film, audio tape recording, field notes, interview and focus group transcripts.

While communication studies define culture as a static phenomenon in terms of knowledge, discourse approach and sees it as dynamic. According to discourse approach to intercultural communication each person is situated within more than one discourse in any given time. Scollon and Scollon $(1995,2001)$ illustrate that individuals do not represent one stereotypical culture, but "our identities as participants in speech events are both developed and maintained in interpersonal communication" $(1995,13)$. On the other hand, Porter and Samovar (1991) assume that cultures are static and individuals in a given culture represent the characteristics of that culture. Therefore, while communication studies compare cultures to understand intercultural communication and possible breakdowns, discourse studies examine actual interaction between people to examine interdiscourse communication. Moreover, while Porter and Samovar (1991) assume that knowledge about different cultures will solve intercultural communication problems, Scollon and Scollon (2001) assume that people need not only the knowledge about different cultures, but also the tolerance of ambiguity, since both languages and communication process are ambiguous.

\section{Critical Approaches to Intercultural Communication}

Pennycook $(1994,2001)$ adds another dimension to intercultural communication field by problematizing it. He questions and discredits the assumptions that the spread of English is a natural and neutral process, and that the use of English for intercultural communications will be beneficial. Pennycook (1994) states that the discourse of English as an International Language (EIL) "has moved from a rhetoric of colonial expansion, through a rhetoric of development aid to a rhetoric of the international free market" (6) and therefore English carries the colonial past that teachers and language users need to be aware of. Pennycook (2001) further argues that contrary to current belief, access to standard English will not bring social and economic advantages to learners. Instead, he promotes to decenter English language and culture education and to give 'voice' to language learners by localizing the teaching of English.

Pennycook (1994) proposes to not only "decolonize English" (321) but also "decolonize the colonizers' minds" (321) so that "English can be appropriated and used for diverse ends, it may, by dint of its widespread use, offer interesting possibilities for the spread of alternative forms of culture and knowledge and for new forms of communal action" (321). He states that decolonization of the mind and language can be done through discourses (interdiscourse communication) between 'colonized' and 'colonizers', post-colonized and post-colonizers, and through critical pedagogy, which allows language learners to have voice.

Like Pennycook (1994), Phillipson (1992) also examines the spread of English from critical approach. However, Phillipson argues that English language replaces local languages and cultures. In Japanese context, Kubota (1998) illustrates that although English is not replacing Japanese, it affects the communication style of Japanese. According to Kubota (1998) the general tendency in Japan in relation to written discourse is that "English communication pattern is better than Japanese and should be emulated" (299). Like Pennycook, Kubota (1998) also proposes critical pedagogy as the solution to transform current dominance of English 
language and western culture in Japan.

Within poststructuralist perspective critical pedagogy is defined as "education grounded in a desire for social change" (Pennycook, 1994, 297). Canagarajah (1999) discusses the changes that critical pedagogy envisions in language education in relation to what he calls 'pedagogy of mainstream'. While mainstream pedagogy considers learning merely a cognitive activity, critical pedagogy views learning in relation to learner, her background, and her learning experiences.

Furthermore, critical pedagogy posits the learner in her social, cultural context, and acknowledges that school is not a neutral site but it is influenced by larger social, political context that it is situated. Unlike mainstream pedagogies, critical pedagogy does not consider learning process as universal but cultural. Since, knowledge is socially constructed; there is not one universal reality that applies to all settings. Therefore, teaching methods of dominant communities may create conflict in dominated communities. Moreover, according to critical pedagogy knowledge is not value-free. Knowledge carries the moral, cultural, and ethical values. Therefore, the institutionalized knowledge carries the assumptions and perspectives of the dominant groups, and imposes the values of this group to subordinate groups which may have their own "competing versions of reality that favor their own interest" (Canagarajah, 1999, 16).

In critical pedagogy, the teachers are seen as "transformative intellectuals", who works for social transformation (Pennycook, 1994). Teachers' job is not to transfer a body of knowledge to students but to overcome the division between theory and practice and work for social change. Thus, teacher is seen not as a technician but as an intellectual, who works with people. Therefore, critical pedagogy should "start with ways of critically exploring students' cultures, knowledges, and histories in ways that are both challenging and at the same time affirming and supportive" (Pennycook, 1994, 311).

Canagarajah (1999) identifies two types of critical pedagogy, 'reproduction theories' that are based on deterministic perspective of power, and poststructuralist 'resistance theories'. According to 'reproduction' orientation 'subjects are passive, and lack agency to manage linguistic and ideological conflicts to their best advantage; languages are seen monolithic, abstract structures that come with a homogeneous set of ideologies and function to spread and sustain the interest of dominant groups" (Canagarajah, 1999, 2). On the other hand, according to 'resistance theories', "subjects have the agency to think critically and work out ideological alternatives that favor their own empowerment. It recognizes that while language may have a repressive effect, it also has the liberatory potential of facilitating critical thinking, and enabling subjects to rise above domination" (Canagarajah, 1999, 2).

Pennycook (1994), Phillipson (1992) and Canagarajah (1999) examine interdiscourse interactions between the native and nonnative speakers of English in relation to unequal power dynamics. While center countries exercise power by making decisions regarding language teaching methods and materials and hence determining the appropriate form of intercultural communication through English, periphery countries need to transform language pedagogies through 'appropriation' and to redefine English in their context in order to transform the current interdiscourse interactions in the world (Canagarajah, 1999; Kubota, 1998; Pennycook, 1994).

\section{Teaching English for Intercultural Communication}

Recently, English has been defined as an international language through which people from various nations and cultures communicate with (Alptekin, 2002; Crystal, 1997; McKay, 2002). However, despite its international status, English is still taught depending on the native speaker notion of 'communicative competence'. The notion of 'communicative competence' was developed by Hymes in relation to first language acquisition and use. Later, Canale and Swain applied this notion to foreign/second language teaching field and identified four competencies (grammatical competence, sociolinguistic competence, discourse competence, and strategic 
competence). According to this notion, English language learners are expected to master the native speakers' communicative competence. However, teaching English depending on a native speaker norm has been criticized (Alptekin, 2002; Byram, 1997, Sridhar, \& Sridhar, 1992) in terms of setting an impossible objective, which leads to failure, and creating a wrong type of competence which requires giving up one language and culture in order to be accepted as a native speaker (Byram, 1997; Norton, 1998; Brutt-Griffler, \& Samimy, 2001). Instead of taking native speaker as a model and replacing one's native language and culture with English language and the culture of English speaking nations; bilingual speaker based notion of 'intercultural communicative competence' is suggested to be a model of ELT (Alptekin, 2002; Byram, 1997).

Although Alptekin (2002) did not propose a model for intercultural communication, he identified the criteria that such a model needs to take into account. The criteria that Alptekin (2002) proposed are: a) instead of native speakers successful bilinguals with intercultural insight needs to be taken as a model; b) English as an International Language (EIL) pedagogy should be appropriate at both global and local context; c) instructional materials and activities should involve local and international context; $d$ ) instructional materials should have discourse samples from nonnative speaker interactions as well as native speaker interactions; e) learners should be equipped with linguistic and cultural awareness to develop intercultural competence.

The most comprehensive model of "intercultural communicative competence" is developed by Byram's (1997). This model involves four competencies: linguistic competence, sociolinguistic competence, discourse competence, and intercultural competence. Although he represents other competencies in his model, he mainly focuses on the aspects of intercultural competence. According to Byram (1997) intercultural competence involves four factors: attitudes, knowledge, skills and political/critical education.

In the model, attitudes are considered a prerequisite for successful intercultural communication. Attitudes refer to "curiosity and openness, readiness to suspend disbelief about other cultures and belief about one's own" (Byram, 1997, 50). In order to suspend one's belief and to analyze those beliefs from another point of view, one needs to 'decentre'. Ability to decentre is fundamental in understanding other cultures. Byram (1997) argues that although gaining knowledge about other cultures does not cause positive attitudes toward that culture, knowledge may make it easier to "relativise one's own meaning, beliefs, and behaviors through comparison with other's" (35).

The second component of the model, knowledge, has two categories: a) "knowledge about social groups and their cultures in one's own country, and similar knowledge of the interlocutor's country" and b) "knowledge of the process of interaction at individual and societal levels" (Byram, 1997, 35). Hence, knowledge involves not only the information about our culture and other cultures, but also the awareness of how our knowledge is constructed through socialization in our culture. Therefore, intercultural speaker needs to understand the socialization process and how this process creates different perceptions in different societies. Byram (1997) states that "awareness that one is a product of one's own socialization is a precondition for understanding one's reactions to otherness. Similarly, awareness of how one's 'natural' ways of interacting with other people are the 'naturalised' product of socialization, and how parallel but different modes of interaction can be expected in other cultures, is part of the knowledge an intercultural speaker needs" (52).

Third component of the intercultural communicative competence is skills. Byram (1997) illustrates two types of skills: a) skills of interpreting and relating, which refers to "ability to interpret a document or event from another culture, to explain it and relate it to documents from one's own" (52) and b) skills of discovery and interaction, which refers to "ability to acquire new knowledge of a culture and cultural practices and the ability to operate knowledge, attitu- 
des, and skills under the constraints of real-time communication and interaction" (52). The skills of interpreting and relating allows intercultural speaker to identify ethnocentric perspectives in documents such as television reports, textbooks, or tourist brochures, and in conversations. This skill is closely related to the knowledge of how ethnocentric perspectives are acquired through socialization. The skill of discovery and interaction allows intercultural speaker to understand new culture by acting like an ethnographer. According to Byram (1997), "the skill of discovery is the ability to recognize significant phenomena in a foreign environment and to elicit their meanings and connotations, and their relationship to other phenomena" (38).

The last component of the model is political education and critical cultural awareness, which refer to "an ability to evaluate critically and on the basis of explicit criteria perspectives, practices and products in one's own and other cultures and countries" (53). Byram (1997) promotes to teach intercultural education within political education framework to develop students' critical cultural awareness. According to Byram (1997) an intercultural speaker needs to "use sources (e.g. reference books, newspapers, histories, experts, lay informants) to understand both contemporary and historical political, economic and social relationships between cultures and societies and analyze the differing interpretations involved" (63). Furthermore, intercultural speaker needs to be aware of her own ideological perspective and values (liberal, socialist, Muslim, etc.) and potential conflict between her ideology and other ideologies. According to Byram (1997), language teachers need to equip learners with the knowledge, attitudes, and skills for intercultural communication within political education framework, which develops critical cultural awareness.

Another useful notion (third place) for intercultural communication is proposed by Kramsch (1993). According to Kramsch (1993) "the only way to start building a more complete and less partial understanding of both C1 [native culture] and C2 [target culture] is to develop a third perspective, that would enable learners to take both an insider's and an outsider's view on C1 and C2. It is precisely this third place that cross-cultural education should seek to establish" (210). The goal of teaching English for intercultural communication is not to assimilate learners into target culture, but enable them to find an intercultural place, which is beyond their culture but not in target culture. It is a "third space", where learners can maintain their own identity as a member of their native culture and at the same time interact with the members of other cultures without being ethnocentric.

\section{Conclusion}

In the current age of globalization, intercultural communications have become the inevitable aspects of our multicultural lives. Since the current aim of English language teaching is defined as enabling our students to communicate in English, English language classrooms seem to be the best environments not only to teach the language but also to raise students' awareness about cultures and the intercultural aspect of communication.

However, since we seem to redefine the role of English in the world as an international language, we also seem to redefine the cultures, role of cultures in language teaching and the way we teach English. It seems like we no longer view culture as a static notion which can be transferred to students. Instead, cultures are seen as dynamic notions, which involve set of practices in various dimensions (gender, age, profession, etc).

Furthermore, it seems like we have also transformed the way we teach English by questioning the appropriateness of taking native speaker as a norm and leading our students to assimilate into target culture. It is proposed to take successful bilinguals as a norm in teaching English as an international language and enable language learners to gain cultural knowledge, positive attitudes, and skills, which would allow them to find their third place to have successful intercultural communications. 
Bio

Yeşim Bektaş-Çetinkaya, PhD., is an Assistant Professor at Dokuz Eylul University. She studied at the Ohio State University where she earned her MA. and PhD. in foreign language education. Her research interests include teaching English for intercultural communication, affective variables, and second language literacy.

\section{REFERENCES}

Alptekin, C. (2002). Towards intercultural communicative competence in ELT. ELT Journal, 56, 57-64.

Argyle, M. (1991). Intercultural communication. In L. A. Samovar, \& R. E. Porter (Eds.), Intercultural communication: Reader. (pp. 32-45). Belmont, CA: Wadsworth Publishing.

Barna, L. M. (1991). Stumbling blocks in intercultural communication. In L. A. Samovar, \& R. E. Porter (Eds.), Intercultural communication: Reader. (pp. 345-353). Belmont, CA: Wadsworth Publishing.

Barnlund, D. C. (1991). Communication in a global village. In L. A. Samovar, \& R. E. Porter (Eds.), Intercultural communication: Reader. (pp. 22-31). Belmont, CA: Wadsworth Publishing.

Brutt-Griffler, J., \& Samimy, K. K. (2001). Transcending the nativeness paradigm. World Englishes, 20, 99-106

Byram, M. (1997). Teaching and Assessing Intercultural Communicative Competence. Clevedon: Multilingual Matters.

Canagarajah, A. S. (1999). Resisting Linguistic Imperialism in Teaching English. Oxford: Oxford University Press.

Crystal, D. (1997). English as a Global Language. Cambridge: Cambridge University Press.

Gersten, B. F.,\& Tlusty, N. (1998). Creating intercultural contexts for cultural communication: Video exchange projects in the EFL/ESL classrooms. TESOL Journal,7, 11-16.

Gudykunst, W. B., \& Mody, B. (2002). Handbook of international and intercultural communication. Thousand Oaks: Sage.

Hall, E. T. (1991). Context and meaning. In L. A. Samovar, \& R. E. Porter (Eds.), Intercultural communication: Reader. (pp. 22-31). Belmont, CA: Wadsworth Publishing.

Kramsch, C. (1993). Context and culture in language teaching. New York: Oxford University Press.

Kramsch, C. (2001). Intercultural communication. In R. Carter, \& D. Nunan (Eds.), The Cambridge guide to teaching English to speakers of other languages. (pp. 201-206). Cambridge: Cambridge University Press.

Kubota, R. (1998). Ideologies of English in Japan. World Englishes, 17, 295-306.

Kubota, R. (2001). Teaching world Englishes to native speakers of English in the USA. World Englishes, 20, 47-64.

McKay, S. L. (2002). Teaching English as an International Language. Oxford: Oxford University Press.

Norton, B. (1998). Rethinking acculturation in second language acquisition. Prospect: A Journal of Australian TESOL, 13, 4-19.

Pennycook, A. (1994). The Cultural Politics of English as an International Language. New York: Longman Group Limited.

Pennycook, A. (2001). Critical Applied Linguistics. Mahwah: Lawrence Erlbaum.

Philipson, R. (1992). Linguistic Imperialism. Oxford: Oxford University Press.

Porter, R. E., \& Samovar, L. A. (1991). Basic principles of intercultural communication. In L. A. Samovar, \& R. E. Porter (Eds.), Intercultural communication: Reader. (pp. 5-21). Belmont, CA: Wadsworth Publishing.

Rogers, E. M., \& Hart, W. B. (2002). The histories of intercultural, international, and development communication. In W. B. Gudykunst, \& B. Mody (Eds.), Handbook of international and intercultural communication. (pp. 1-19). Thousand Oaks: Sage.

Samovar, L. A., \& Porter, R. E. (1991). Intercultural Communication: Reader. Belmont, CA: Wadsworth Publishing.

Scollon, R. (2001). Intercultural communication and ethnography: Why? And why not? In C. Barron, N. Bruce, \& D. Nunan (Eds.). Knowledge and discourse. (pp. 300-314). New York: Longman.

Scollon, R., \& Scollon, S. W. (1995). Intercultural communication: A discourse approach. Malden, MA: 
Blackwell.

Scollon, R., \& Scollon, S. W. (2001). Discourse and intercultural communication. In D. Schiffrin, D. Tannen, \& H. E. Hamilton (Eds.). The handbook of discourse analysis. (pp. 538-548). Malden, MA: Blackwell.

Scollon, R., \& Scollon, S. W. (2001). Intercultural communication: A discourse approach. Malden, MA: Blackwell.

Sridhar, K. K., \& Sridhar, S. N. (1992). Bridging the paradigm gap: Second language acquisition theory and indigenized varieties of English. In B. B. Kachru (Eds.), The other tongue: English across cultures. (pp. 27-47). Urbana: University of Illinois Press.

Triandis, H. C., Brislin, R. W.\& Hui, C. H. (1991). Cross-cultural training across the individualism-collectivism divide. In L. A. Samovar, \& R. E. Porter (Eds.), Intercultural communication: Reader. (pp. 5-21). Belmont, CA: Wadsworth Publishing.

Yum, J. O. (1991). The impact of Confucianism on interpersonal relationships and communication patterns in East Asia. In L. A. Samovar, \& R. E. Porter (Eds.), Intercultural communication: Reader. (pp. 5-21). Belmont, CA: Wadsworth Publishing. 